\title{
Hadith Content
}

\section{Some of It Requires a Big Pinch of Salt}

While acknowledging the limitations of the hadith corpus described above, it is a fact that without these hadith collections we would know very little about what the Prophet said or did during his lifetime besides relaying the Qur'anic verses, because the holy book itself references very few events from his life on a practical level. ${ }^{1}$

And where would we be without the moving and inspiring accounts demonstrating Muhammad's scrupulous fairness, admirable pragmatism, pronounced sense of empathy including towards animals, exemplary respect for other religions, generosity of spirit, touching gallantry, wondrous approachability, Job-like steadfastness in the face of immense personal sorrow every time he buried a young or adult child (six in total), humility with his wives and around housework, and love of nature and of his grandson, for that matter, whom he would happily allow to climb on his back while he prostrated in prayer, then gently set aside before arising

${ }^{1}$ Lang, Jeffrey. 1995. Struggling to Surrender: Some Impressions from an American Convert to Islam. Maryland: Amana Publications, 75-76. Or see Chap. 1, footnote 6 for full quote.

(C) The Author(s) 2022

L. El-Ali, No Truth Without Beauty, Sustainable Development

Goals Series, https://doi.org/10.1007/978-3-030-83582-8_3 
and picking him back up to place on his shoulders as he went through the prayer motions? ${ }^{2}$

However if you are anything like me, at some point in your life (especially lately) you must have heard or read some hadith cited from one of the great Sahih compilations of Bukhari or Muslim or al-Nasa'i or alTirmidhi or some other reputable source that made you frown and drop your jaw at the same time, while leaving you tongue-tied in incredulity or exasperation. So having given the reader a sense of the fluid boundaries of hadith, let me now try to summarise some key points relating to the content of the hadith collections that I hope will be helpful.

As will have become evident from the previous chapter on the corpus of hadith reports, if you have always assumed that any hadith cited from one of the two Sabih or other collections of the scholars listed above must:

(a) Be attributable to the Prophet,

(b) Have both a solid (unbroken) and sound (reliable) chain of transmitters, and

(c) Relay a verified saying or event,

then like me, you would have been wrong. It must be noted here that at least part of the problem must surely come from the fact that the two most recognised compilations are called Sahih, which means "true" or "authentic" in Arabic.

In brief, here is what we must know about the hadith collections in terms of who transmitted the individual hadiths, the validity of the hadiths in these collections, and the process followed by early scholars in compiling their collections.

\section{Attribution: Who SAid That?}

Alongside the reports attributed to the Prophet, the Sunni hadith collections often also include reports attributed to Muhammad's Companions and later figures, while the Shia ones always include reports attributed to

\footnotetext{
${ }^{2}$ al-Tirmidhi compilation (in Arabic). No. 3784. www.islamweb.net/ar/library/index. php?page=bookcontents \&ID=3717\&bk_no=2\&flag $=1$.
} 
the imams. ${ }^{3}$ Additionally, the scholars' own commentaries are often included in the mix.

\section{All these reports are commonly-and confusingly-referred to as hadith!}

These hadith scholars did not seek to conflate the Prophet's sayings or actions with those of his Companions or successors or descendants or their own, and did label reports accordingly. It is we who stopped asking the question, freezing before anything someone might announce is a " hadith", assuming it must be both a verified quote or event and one attributed to the Prophet himself, and a binding directive at that (as opposed to even, say, a casual observation or act he might have made).

This is not to say that there is no value or truth in any of these other reports or commentaries by other figures - there often is - but to highlight a common yet critical misconception that can have negative implications.

For example, one of the great ironies of hadith history is that even as early Sunni Islam vociferously prioritised the rooting of law directly in the Qur'an and in the Prophet's example, the result was that the first several centuries of Islam ended up placing more stock in the pronouncements of the jurists, "...often above or despite scripture...custom could create scripture and...the ulama [jurists] acknowledged this." 4

Basically, the scholars/jurists did not shy away from openly using weak hadith to justify establishing a certain law if in their own minds they were doing so for the greater good, in so far as they believed that

\footnotetext{
${ }^{3}$ Brown, Jonathan. 2014. Hadith: Muhammad's Legacy in the Medieval and Modern World. London: Oneworld Publications, 123-126. In Shia Islam, since the Prophet's authority was believed to live on in select members of his family known as imams, then the imams own sayings constituted hadiths to be recorded in the corpus. The first imam was Ali, who was the cousin, son-in-law and Companion of the Prophet who became the fourth caliph after his death, and the eleventh imam was Hasan al-'Askari, who died in captivity in the year 874 with no apparent heir, although Twelver Shiism believes he did have a son (the twelfth imam) who went into hiding to escape the tyranny of the Abbasid caliph who had imprisoned his father. The Shia hadith corpus also places great stock in the imams themselves as transmitters of the Prophet's sayings and actions, whether alone or as part of a chain of transmitters, given their perceived authority as derived from the Prophet himself.

${ }^{4}$ Brown, Jonathan. 2015. Misquoting Muhammad: The Challenge and Choices of Interpreting the Prophet's Legacy. London: Oneworld Publications, 177.
} 
prevailing custom carried an inherent legitimacy, or "lawfulness", in their societies. ${ }^{5}$

But the weight accorded to the opinion of the scholars at the expense of scripture-whether the Qur'an itself or the Prophet's genuinely recorded example-arguably had its most negative and lasting impact in matters relating to women:

...even in Bukhari and Muslim and other Sabih collections, contradictory traditions (hadiths) abound that give both sides of the argument, with the noteworthy exception of traditions on some women's issues-especially regarding matters of social status and rights-in which only one side of the argument, the restrictive, is documented. ${ }^{6}$

Needless to say, one wonders why women's issues were singled out for such a departure from the scholars' own methodological construct for compiling hadith. The only reasonable explanation I have found is the following: that the scholars were determined to "regulate" as much of life as possible i.e. to act as jurists and not only as scholars, and in the process felt that customs relating to women that were widely held to be desirable had to have solid scriptural backing, meaning a single argument rather than several, to underpin their regulation, or institutionalisation. After all as we have seen, it was typical of the ninthcentury hadith scholars to openly declare that their primary interest in collecting hadith was to derive laws. And even the scholar Muslim, who resisted including any commentaries in his compilation, had declared (in self-defence) that he had left out authentic hadiths when he believed that not everyone would agree to their authenticity! ${ }^{7}$

Even more alarming is the fact that it is in hadith that we find exceptionally offensive views on women, many of which were inserted into the official corpus of hadith as late as the eleventh century-a full 100

\footnotetext{
${ }^{5}$ It was somewhat reassuring to learn that while these efforts to derive and establish laws were loud and forceful, there is significant evidence to suggest that the majority of the thinking in those early centuries of Islam was that the Prophet as a role model is actually best honoured by applying the virtues and principles he exemplified to both secular and sacred challenges, outside of the realm of law.

${ }^{6}$ Stowasser, Barbara Freyer. 1994. Women in the Qur'an, Traditions, and Interpretation. New York: Oxford University Press Inc.,105.

${ }^{7}$ Brown, Jonathan. Op. Cit. (2014), 38.
} 
years after the great compilations were officially concluded. ${ }^{8}$ Among the most shocking are:

....images of women as 'morally and religiously defective,' 'evil temptresses, the greatest fitna [source of discord] for men,' 'unclean over and above menstruation,' 'the larger part of the inhabitants of Hell, because of their unfaithfulness and ingratitude to their husbands,' and as having 'weaker intellectual powers,' therefore being unfit to rule politically. ${ }^{9}$

Interestingly, of the nearly 20,000 different hadiths or 70,000 total (i.e. including variations on the same hadith) in the official corpus, there are only about 6 offensive ones about women that are (somehow) designated as reliable ${ }^{10}$ yet these have come to dominate the discourse at the expense of those hadiths that

...emphasize women's full humanity; counsel husbands to deal kindly and justly with their wives; confirm the right of women to acquire knowledge; elevate mothers over fathers; ... record women's attendance at prayers in the mosque during the Prophet's lifetime, including an incident where a girl played in front of him as he led the prayer; affirm that many women (including women from the Prophet's family) went unveiled in the later years of Islam; and record that the Prophet accepted the evidence of one woman over that of a man. ${ }^{11}$

We will see in later chapters of this book the extent to which the Prophet had been met with resistance to his extraordinarily emancipatory agenda with regard to women, even when a directive would have just come verbatim from God in the form of a Qur'anic verse on a particular issue.

\section{Transmission: Weak hadiths (and Bad Laws), Myths, Forgeries And Mixed Intentions}

Most Muslims grow up believing, as I did, that all hadith attributed to the Prophet in any of the reputable compilations - whether the Sabibs or any of the works that came before them that they built upon, such as the

\footnotetext{
${ }^{8}$ Barlas, Asma. 2015. Believing Women in Islam: Unreading Patriarchal Interpretations of the Qur'an. Texas: University of Texas Press, 45.

${ }^{9}$ Ibid.

${ }^{10}$ Ibid., 46.

${ }^{11}$ Ibid.
} 
musannafs, musnads or sunans-is $100 \%$ true as it was verified as such by the great scholars of the day.

But we have seen that hadith with weak and even doubtful chains of transmission were included even in the great hadith compilations, though most (not all, as in the case of Ibn Majah for example) were recognised as such at the time and so labelled. They were included not out of mischief, but because these scholars thought the weak and even suspect hadith might have a useful purpose nonetheless.

Yet we have also seen that the scholars with a juristic bent (not all were) had no qualms about going so far as to use weak hadith to derive laws when they thought the end justified the means. To their minds, a weak chain of transmission represented more of "an absence of evidence than evidence of absence." 12 To my mind this is unspeakably presumptuous, to put it mildly, because once a law is established anywhere it becomes close to impossible to revise or rescind it, especially if it has been assigned the label "Islamic" and come to be widely believed to be so.

At least as great as the harm caused by deriving laws from weak hadiths was the harm done by the everyday reach of weak hadiths, in so far as they undoubtedly influenced and arguably restricted what piety looked and sounded like. For example weak hadiths were regularly used by preachers, yet even the esteemed Ibn Hanbal, who had tutored all of Bukhari, Muslim and Abu Dawūd, is recorded to have said of such preachers:

How useful they are to the masses, even though the mass of what they say is false. ${ }^{13}$

The scholars' laissez-faire attitude towards the use of weak hadiths by preachers reverberates to this day, as modern scholars mostly have no qualms about placing efficacy above accuracy:

'If a layperson comes to me off the street and asks me if there are mistakes in the Two Authentic Collections (Sabihayn) of Bukhari and Muslim,' admitted one modern Egyptian Hadith scholar privately, 'I'd tell them no. But among the ulama [jurists],' he added, 'we all acknowledge that the two books have errors-there is no perfect book but the Book of God.' ${ }^{14}$

${ }^{12}$ Brown, Jonathan. Op. Cit. (2015), 225.

${ }^{13}$ Ibid., 226.

${ }^{14}$ Ibid., 224-5. 
So if the prevalence and use of weak hadiths was so widespread so early on, how many of them are there that we should be wary of?

When I first contemplated this question, I felt certain that these weak hadiths would represent a small portion, a tiny minority, of what was documented and is, of course, still out there. Alas, it turns out I was wrong.

The reality is that Muslim scholars themselves maintained that even if we look only at those hadiths that have been authenticated, i.e. determined to be of sound transmission, only a few dozen Prophetic hadiths at most can be said to be reliable with absolute certainty, though many others can be said to be "most probably" reliable. ${ }^{15}$ Still, contrast that, for a moment, with the 19,600 that the tenth century's Six Books of hadith ultimately come to, or with the 600,000 that Bukhari had started with or the 750,000 that Ibn $\mathrm{Hanbal}^{16}$ had sifted through before him.

This number - of a few dozen "absolutely reliable" hadiths and perhaps a few dozen more "most probably reliable" hadiths-rather than hundreds let alone thousands or tens of thousands, certainly rings true from my personal experience, as I have encountered wildly different types of hadiths on a given topic in communities across the Muslim world, many which clash disturbingly with my understanding of the message of the Qur'an and the beauty of God.

But if only the inclusion of weak hadiths, in terms of their transmission mechanisms, were the sole challenging issue with the hadith collections!

We have already seen that scholars of all backgrounds agree that the Qur'an has remained unchanged from when it was first written down. Conversely, all scholars also agree that there was massive hadith forgery, including the scholars and jurists of those first few centuries of Islam who produced the great hadith collections. In fact, those early jurists readily admitted "that they had themselves uncovered thousands and thousands of forged hadiths." 17

Why would the early generations of Muslims, presumably more faithful than later generations due to their proximity to the Prophet and his immediate legacy, have wilfully forged hadiths, when the Prophet's every word (and deed) was deemed second only to God's?

\footnotetext{
${ }^{15}$ Ibid., 232.

${ }^{16}$ Ibid., 44.

${ }^{17}$ Ibid., 9.
} 
A primary motive for forging hadiths has been found to be religious zeal. And even with the revered "authentic" hadith compilations we have been discussing, the compilers' motives were not only to record historical data but to also institutionalise the Prophet's exemplary behaviour as a model for the community. ${ }^{18}$ In other words, it would seem that the approach of "the end justifies the means" was adopted even by the great compilers not only to establish desired laws, but also to prop up the Prophet as a role model-as though his true example needed any embellishment!

It should be clarified though that there was unanimous agreement among the scholars not to use forgeries to derive laws as such ${ }^{19}$ - only for embellishing accounts relating to the Prophet. I suppose we should feel relieved by this, only it is hard to be grateful when they did not exhibit the same degree of responsibility when it came to using weak hadiths in legal matters, which can be just as harmful or possibly more so. In any case, this means that any forged hadiths found in the compilations are unlikely to touch upon legal issues. The scholars were willing to use forgeries if it served a good purpose outside of the legal sphere, and they did so even as they consistently condemned the intentional forging of hadiths, even if for a good cause, as did their successors without exception throughout the centuries. ${ }^{20}$

In everyday modern terms, consuming a product while at the same time condemning its very production seems not just contradictory but hypocritical, unless one takes the magnanimous view that the inherently immoral product was being turned against itself by being put to good use. The only problem with this is that a precedent would have been set, in this magnanimous interpretation, for future generations to embrace blatant untruths any time they deemed there to be a good reason to do so. I think many of us have known or heard of the negative consequences of such an approach in many of today's hyper-religious yet arguably irreverent environments.

A second motive for forging hadiths was, unsurprisingly, politics. The first 60 years after the Prophet's death were rife with conflict and outright civil war. To borrow a few words that convey the tragic point:

\footnotetext{
${ }^{18}$ Stowasser, Barbara Freyer. Op. Cit., 104.

${ }^{19}$ Brown, Jonathan. Op. Cit. (2015), 225.

${ }^{20}$ Ibid., 224.
} 
Eager to insinuate their ideas and customs into the new religion, parties from every religious and political direction began placing their messages in the Prophet's mouth. Hadiths-reports of the Prophet's words and deedswere forged by the thousands. ${ }^{21}$

Thus the Sunni-Shia split, as well as more secular political conflicts, spawned an industry of propaganda on both sides that indulged in forging hadiths to prop up each side's arguments. Ironically, the birth of the Sunni-Shia split is itself rooted not so much in the forgery of hadithbecause both sides had heard the Prophet say the same thing honouring Ali, his cousin and son-in-law whom the Shia in particular revere-but in the fact that different people had interpreted such hadith differently. ${ }^{22}$

A third motive for forging badiths was chauvinism in its various stripes, ${ }^{23}$ including male chauvinism. While wilfully forging Prophetic hadith is outrageous whatever the motive, it is when aimed at demeaning women-literally one-half of humanity across the ages- that it hits the lowest rung of the human character. Ugly falsehoods about women and other topics were spread in earnest after the Prophet's death, along with perfectly good hadith, by at least one Companion of the Prophet (Abu Hurayra), who is recorded to have infuriated such towering Companions as Omar, Ali and Aisha (the Prophet's wife) to the point that they all angrily challenged and even threatened him, in one case, in response. ${ }^{24}$ Yet these falsehoods are recorded, alongside the noble words of the Prophet, in the same hadith volumes. I cannot bring myself to relay any of these unsavoury claims here because I would be committing the act of consuming the product myself by propagating it, though I thank the Muslim scholars who have brought this evidence to light for us from the bottom of my heart. Besides, they are too ugly for a book trying to shine a light on the beauty of the Qur'anic message, one that's trying to scrape away the monstrous accumulation of man-made mould that has all but smothered it.

${ }^{21}$ Ibid., 22.

${ }^{22}$ Brown, Jonathan. Op. Cit. (2014), 70.

${ }^{23}$ Ibid., 71-73.

${ }^{24}$ Abou El Fadl, Khaled M. 2003. Chap. 7, Faith-Based Assumptions and Determinations Demeaning to Women in Speaking in God's Name: Islamic Law, Authority and Women. Oxford: Oneworld Publications. 
For the record, it must be mentioned here that these hadith forgeries could take the form of either complete fabrications or of assigning someone else's sayings to the Prophet.

Also for the record, there were forgeries not only of Prophetic hadiths but also of chains of transmission, such as when someone wanted to establish a report as a Prophetic hadith or boost the credibility of a particular existing hadith. ${ }^{25}$ This is no secondary issue: Chap. 2, "Hadith Corpus", alluded to how the compiling scholars Bukhari et al. were more concerned with assessing the chain of transmission than with assessing the content of hadiths, which will be discussed further below.

Lastly, for the sake of completion, we should know that Shia Islam had to grapple with similar forgeries stemming from similar motives, which is primarily what led al-Kulayni and Ibn Babawayh in the eleventh century to produce their hadith compilations after the twelfth imam had vanished (whether through death or occultation is irrelevant for our purpose here). In the absence of a living imam (direct heir-descendant of the Prophet) whom the Shia community could cross-check everything with, a need to safeguard true hadith became evident. Having said this, the Sunni and Shia hadith traditions have never been totally separate bodies of knowledge, as they share common origins and overlap significantly, especially with regard to devotion to the Prophet's family. ${ }^{26}$

\section{Process: Far from a Perfect Methodology}

The amount of energy and depth of commitment involved in the process of collecting and sorting hadith is hard for me to even begin to wrap my head around. It truly was a monumental achievement by all these scholars, one that is a rightful source of pride for all Muslims, even if I am drawing attention here to its imperfections.

One of the disconcerting issues with the process of hadith collection is the fact that the compiling scholars prioritised verification of a hadith's chain of transmitters over and above verification of its content. To put it simplistically, they felt that tracing the path of the courier-pigeon and scoring that path for likelibood was more important than assessing the nature and implication of the delivered package. I have to believe that they did this in a bid to remain as neutral as possible about any

${ }^{25}$ Brown, Jonathan. Op. Cit. (2014), 75.

${ }^{26}$ Ibid., 133-137. 
"badith" they may have come across, but in light of their ultimate willingness to use weak hadiths to derive laws and in light of the massive number of forgeries they themselves were uncovering along the way and watching preachers propagate, it seems to me that more emphasis on assessing a hadith's message was called for in determining authenticity. Ultimately, authenticity must stem from compatibility with the Qur'anic message, and not from tracing a centuries-long chain of who said what to whom about the Prophet having said or done something.

A second troubling feature of hadith collection, which at this point should come as no surprise to the reader, is that the compiling scholars dwelt more on verifying the chain of transmission for a hadith with legal implications than they did for a hadith relating to morality or manners. ${ }^{27}$ We have already seen that the ninth-century hadith compilers were driven by an interest in legal matters and in acting as jurists. This was something they openly acknowledged:

Ibn Hanbal drew on the words of one of his teachers when he stated, 'If Hadiths are related to us from the Prophet concerning rulings of the Shariah and what is licit and prohibited, we are rigorous with the chains of transmission.' 'But if we are told Hadiths dealing with the virtues of actions, their rewards and punishments [in the Afterlife], permissible things or pious invocations,' Ibn Hanbal qualified, 'we are lax with the chains of transmission. ${ }^{28}$

It is this unequal rigor in the treatment of legal and moral matters when collecting hadith from the beginning-which caused a far greater proportion of the compiled hadith dealing with morality to be classified as weak hadith - that made possible the psychological inclination of these very scholars to be lax with preachers spreading dodgy hadiths to make whatever point they had in mind. ${ }^{29}$ I suppose they must have felt that on balance, more good would result than bad from these dodgy hadiths on morality and manners, never mind that any dodgy hadith on morality was likely to stick and stand out, and many have surely come back to haunt us today.

Thirdly, it was inevitable and is perfectly understandable that the compiling scholars of the ninth century would agree to the use of paraphrasing in recording hadith. Were they to insist on a word-for-word account of

\footnotetext{
${ }^{27}$ Brown, Jonathan. Op. Cit. (2015), 259.

${ }^{28}$ Ibid., 231.

${ }^{29}$ Ibid., 259, 231.
} 
what the Prophet had said exactly, very little material would have been collected on his sayings. After all, many of the hadiths conveyed were things that the Prophet had only uttered once, or were heard by only one person. Thus rather than verbatim, they had to focus on conveying the general meaning of what the Prophet had said, and there was implicit acceptance that this assumed that all the transmitters in a chain had understood the meaning of the Prophet's utterance, or act for that matter, in the first place. ${ }^{30}$

A fourth issue with the process of compiling hadith is a most fundamental one and has been discussed at some length already in the latter part of Chap. 2, "Hadith Corpus". Briefly, the hadiths were not compiled as they were happening nor immediately after the Prophet's death, but two centuries later after many conflicts and several civil wars had taken place. I do not think this fact warrants further comment, though I was interested to learn that there are several hadiths relaying that the Prophet himself had told his followers not to write his words down, lest they be conflated with the Qur'anic verses that were still being written down as they were being revealed by several scribes and in many personal documents. $^{31}$

Finally, it must be mentioned that there are a few supposed "hadiths" included in the final tenth-century compilations that scholars past and present consider utterly absurd, and any sane person would agree. While Arabic is a language that lends itself to hyperbole and the Prophet certainly spoke in parables and metaphor, there is no amount of bending over backwards for either fact that can lend meaning or purpose to these ridiculous and sometimes vulgar reports. ${ }^{32}$ Many medieval scholars had tremendous difficulty with the fact that the compilers of the ninth century had allowed such material, which in any case made no sense whatsoever, anywhere near a compilation about the Prophet. But ultimately these scholars managed to shrug off their concerns, though some later scholars from the nineteenth and early twentieth centuries are known to have lost their faith in the entire hadith corpus as a result. ${ }^{33}$

\footnotetext{
${ }^{30}$ Brown, Jonathan. Op. Cit. (2014), 23.

${ }^{31}$ Ibid., 21.

${ }^{32}$ For illustrative examples, see Brown, Jonathan. Op. Cit. (2015), 69-71.

${ }^{33}$ Ibid., 70-71.
} 
Open Access This chapter is licensed under the terms of the Creative Commons Attribution 4.0 International License (http://creativecommons.org/licenses/ by $/ 4.0 /$ ), which permits use, sharing, adaptation, distribution and reproduction in any medium or format, as long as you give appropriate credit to the original author(s) and the source, provide a link to the Creative Commons licence and indicate if changes were made.

The images or other third party material in this chapter are included in the chapter's Creative Commons licence, unless indicated otherwise in a credit line to the material. If material is not included in the chapter's Creative Commons licence and your intended use is not permitted by statutory regulation or exceeds the permitted use, you will need to obtain permission directly from the copyright holder.

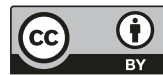

